\title{
Editorial
}

\section{The mysteries of branding revealed}

Some corporate executives seem reluctant to make long-term investments in building their brands. Although they have no doubt heard numerous arguments about how great brands can increase profits and help grow their businesses, they remain unconvinced. For many, branding is still something of a mystery. I find four key principles are most helpful in revealing how branding works.

\section{GAINING CONSIDERATION}

A good starting point for discussion is the adage, 'Products create choices; brands simplify choices'. Leslie de Chernatony and Malcolm McDonald offer a similar perspective with their conceptualisation of a brand as 'product surround'. Some managers may not appreciate this basic distinction between product and brand, so I find it important to emphasise:

- The primary purpose of a brand is to help products and services 'gain consideration' with prospective customers.

Within reason, the more product choices customers have, the better off they are likely to be. But brands play a fundamentally different role. Brands are one of the first things people encounter or think about as they approach a product purchase. When faced with multiple product choices, customers typically do not evaluate all aspects of all possible alternatives. Instead, research shows that most customers look first for meaningful ways of simplifying their decision problem by quickly reducing the alternatives to a 'short list' of contenders - what psychologists call the consideration set.

A customer's final choice is often made by evaluating and comparing only those alternatives found in the consideration set. In industrial settings, the institutional equivalent of an individual's consideration set is the approved vendor list. A primary objective of branding is then to gain consideration with prospective customers for those products and services under the brand's umbrella.

The power of having a brand considered becomes obvious when one realises how small consideration sets typically are. Research shows that most consideration sets have one, two, or occasionally three brands. Prospective customers shopping in the USA for business printers, for example, consider on average 1.5 printer brands before purchasing (often the brand leader Hewlett Packard and perhaps one other manufacturer). If a company's brands are not considered, their products generally will not be purchased.

\section{THE RULE OF ONE}

A fundamental branding objective is to simplify choices. In so doing, branding can be a powerful tool for making promises to customers and managing their expectations about what products and services can (and cannot) deliver. Yet too often companies tie their brands to an expanding array of product features and functions. In markets with changing technologies or shifting preferences, such brands eventually become associated with outdated features or common functions, and thus fall by the wayside. Great brands can live to see many product generations. 
One secret to longevity is to elevate the brand's associations beyond current product features and functions - focus the brand on a single, relevant customer benefit or value. A lasting benefit or value can position the brand for tomorrow's products as well as today's. As products grow more complex and quality becomes more difficult to evaluate prior to purchase, customers rely more on well-known brands that represent safe and simple choices.

Another key to successful brand positioning is singularity - a consistent brand focus on one (and only one) benefit or value. Coca-Cola's internal slogan is 'one sight, one sound, one sell' in marketing its soft drinks; Arthur Andersen promotes 'one vision, one voice, one firm' in its accounting and professional services practice.

Blurred brand positions, however, may lead to increased pricing pressures if customers fail to recognise any meaningful differences and treat branded products as commodities. Manufacturers can resist the homogenisation of brands by seeking relevant points of difference on which to position their brands. Research shows that in markets with homogeneous brands eventually only the top one or two brands remain profitable.

A worthwhile goal is to build what I call a master brand - a brand so dominant in customers' minds that triggering a particular benefit or value instantly evokes the brand. When a brand reaches this top-of-mind awareness, it essentially 'owns' the associated benefit or value with customers.

Research shows that achieving such singular brand strength is a critical factor in moving customers beyond initial consideration to effect their actual purchase behaviour. At the same time, the master brand not only precludes competitive brands from claiming the same benefit or value, its dominant mindshare with customers also reduces the number of other brands they include in their consideration sets. These results all combine to give a master brand an extraordinary advantage over its competition.

In summary, the first principle of branding is:

- The Rule of One A brand should strive to 'own' in customers' minds a single, relevant benefit or value that uniquely differentiates the brand from all others in the market.

\section{THE RULE OF TWO}

Brand associations must be easy for customers to understand and remember, especially as companies build and manage their brands across multiple, dynamic product lines. Organisations that have too readily created new brand and product names now find themselves with a proliferation of weak brands and increasingly complicated brand architectures. For many companies, the net result is too many brand mouths to feed and no big payoffs from branding.

Complex branding strategies are self-defeating if consideration is lost with prospective customers. For example, customers puzzle over software products that have up to five tiers of brands plus more than a dozen co-branded decals on a package. Customers cannot remember so many different brands or make sense of the multiplicity of relationships. Which brand is the real hero?

Some broad product lines do require multiple brands. The brand architecture, however, should still endeavor to make choices simpler, not more difficult. Research on branding effectiveness at $3 \mathrm{M}$ Company and elsewhere has uncovered a basic result. For a given product, individuals can effectively retain at most two tiers of brands in a brand hierarchy. This result leads to an important rule for designing brand architectures.

- The Rule of Two For a given product or service, a brand hierarchy should use 
no more than two tiers of brands at a time with any customer.

The implications of this rule are critical. As costs escalate for developing, supporting, and defending trade marks around the world, organisations typically are finding it more profitable to eliminate their weaker brands and focus on building fewer, yet more powerful brands. Many new brands are now created only for products that can greatly expand an existing market or open significant new opportunities. Such brands are thus developed from the start as strategic platforms for later extensions and other leveraging activities.

This evolution in branding leads naturally to a renewed emphasis on strengthening corporate and family brands. These brands reside at the very top of a brand hierarchy and can be especially important with customers in driving consideration in the purchase process.

\section{GETTING CREDIT FOR BRAND VALUE}

Senior executives facing major brand investment decisions need to have valid long-term brand performance measures to weigh against more familiar short-term measures. Long-term branding opportunities are often undervalued or lost when no adequate brand measures are available.

Leading companies are addressing this need. One principal source of long-term brand value is the loyal portion of the existing customer base. Measures of brand loyalty typically include an estimated value from:

- (a) 'repeat purchasing' of customers buying the same products again; and

- (b) the 'cross-selling' of related products and services under the same brand umbrella to those same customers.

On the other hand, a frequently neglected source of value comes from brand advocacy.
Highly satisfied, loyal customers who become brand advocates (or evangelists) may add new prospects to the customer base by enthusiastically recommending the brand to others. Brand advocates may also include opinion leaders and industry experts, for example, who help influence prospective customers' consideration and purchase decisions.

Brand advocacy can be surprisingly valuable. In one study, a well-known restaurant chain estimated part of its brand's value by looking at frequent patrons who visited its restaurants three or more times a month. The average sales check was about $\$ 4$ per visit, or about $\$ 160$ a year. The estimated life-time contribution of such a brand-loyal customer was about $\$ 5,000$ in direct value.

The indirect value from brand advocacy was initially overlooked. Further study showed that highly satisfied, loyal patrons brought their co-workers, friends, and family to the restaurants. Over time, each of these brand advocates generated about 26 other highly satisfied, loyal patrons. The study concluded that on average each brand advocate contributed a net present value of over $\$ 200,000$ to the restaurant brand. Studies of brand advocacy in other industries give similarly remarkable results.

The enormous value of brand loyalty and brand advocacy leads to another challenge for brands. After a favourable product or service experience, a brand must get credit with customers. If someone else takes this valuable credit away from the brand, the return on one's branding investment will be seriously impaired. Therefore, many companies are establishing various brand evangelism programmes to ensure their brands get a fair share of credit with customers.

\section{CONCLUSION}

Brands have two fundamental purposes to help products gain consideration and get credit with customers. Strong brands try to 
simplify choices by owning a single, relevant benefit or value in customers' minds. As companies recognise the strategic value of their brand assets, more senior executives are becoming brand champions and actively coordinating branding practices across their organisations. Brand leadership transcends brand management as companies seek to anticipate customer needs ahead of the mar- ketplace and position today's brands for tomorrow's products and customers.

\section{Peter H. Farquhar \\ Editorial Board}

Copyright (C) Fox Strategy LLC, 1999.

All rights reserved 